\title{
Determination of Humic and Fulvic Acids in River Waters by Concentration with Anion Exchanger Followed by Centrifugation
}

\author{
Tsutomu Nomizu, Masaki SaNJ, Masataka Hiraide and Atsushi Mizuike
}

Faculty of Engineering, Nagoya University, Nagoya 464, Japan

Keywords Humic acid, fulvic acid, river water, anion exchange, centrifugation

Humic substances are the major organic constituents of fresh waters and play many important roles. For example, they interact strongly with toxic heavy metals ${ }^{1}$ and may be precursors of trihalomethanes formed during water treatment with chlorine. ${ }^{2}$ Humic substances in water are usually divided into two fractions: humic acid, which is soluble in alkaline solutions but precipitates in acid solution, and fulvic acid, which is soluble in both alkaline and acid solutions.

$A$ rapid method based on coprecipitation and flotation was proposed by the present authors ${ }^{3}$ for the separation and determination of humic acid in fresh waters, but it is not applicable to fulvic acid. Humic and fulvic acids can be simultaneously concentrated by low-energy physical sorption on macroreticular nonionic polymers or by anion exchange ${ }^{4}$, and then humic acid alone is separated at $\mathrm{pH} 1$ by centrifugation ${ }^{5}$, although the operational details have not been reported.

In the present work, the optimum conditions are established for the separation of humic and fulvic acids in river water by centrifugation after preconcentration by anion exchange.

\section{Experimental}

\section{Apparatus and reagents}

Figure 1 shows the concentration column, which consists of a sorbent bed and two Pyrex glass parts. A Shimadzu UV-180 spectrophotometer was used with 1and 5-cm cells. A Kubota KH-180 centrifuge was employed with a swing-bucket rotor to carry four 7-ml centrifuge tubes, except for $50000 \mathrm{~min}^{-1}$ with a Hitachi 65P-7 ultracentrifuge with three 5-ml centrifuge tubes.

Diethylaminoethyl(DEAE)-cellulose(60-100 mesh, Eastman Kodak) was sequentially washed in $0.5 \mathrm{M}$ hydrochloric acid ( $1 \mathrm{~h}$ ), water, $0.5 \mathrm{M}$ sodium hydroxide $(1 \mathrm{~h})$ and water, and stored in water at $\mathrm{pH} 7$.

Humic acid (Aldrich Chemical, extracted from peat soil) was purified by repeated dissolution in $0.1 \mathrm{M}$ sodium hydroxide and precipitation in $0.1 \mathrm{M}$ hydrochloric acid. A standard humic acid solution $\left(5 \mu \mathrm{g} \mathrm{ml}^{-1}\right)$ was prepared by dissolving the purified humic acid with $0.01 \mathrm{M}$ sodium hydroxide, neutralizing and diluting; its absorption coefficient was $0.096 \mathrm{~cm}^{-1}$ at $350 \mathrm{~nm}$ at $\mathrm{pH}$ 7. A standard fulvic acid solution $\left(100 \mu \mathrm{g} \mathrm{ml}^{-1}\right)$ was prepared from fulvic acid extracted from soil and purified; 6 its absorption coefficient was $0.170 \mathrm{~cm}^{-1}$.

\section{Recommended procedure}

A $500-\mathrm{ml}$ water sample is filtered through a $0.45 \mu \mathrm{m}$ pore Millipore filter $(47-\mathrm{mm}$ diameter) and passed through a DEAE-cellulose column, $1-\mathrm{cm}$ diam. $\times 1 \mathrm{~cm}$, at a flow rate of $5 \mathrm{ml} \mathrm{min}^{-1}$ to sorb humic substances. They are then desorbed by backward-flow elution with $10 \mathrm{ml}$ of $0.1 \mathrm{M}$ sodium hydroxide at a flow rate of $1 \mathrm{ml} \mathrm{min}^{-1}$. The collected effluent is acidified to $\mathrm{pH} 1$ with $11 \mathrm{M}$ hydrochloric acid to precipitate humic acid and divided into two centrifuge tubes. Then centrifugation is performed at $14000 \mathrm{~min}^{-1}$ for $72 \mathrm{~min}$. The supernatant solution, $4.5 \mathrm{ml}$, in each tube is carefully removed with a pipet; then the two solutions are combined and neutralized with $10 \mathrm{M}$ sodium hydroxide, and the absorbance $(A)$ of the solution is measured at $350 \mathrm{~nm}$ at $\mathrm{pH} 7$ against distilled water as reference. To the remaining $0.5 \mathrm{ml}$ solution in each tube, about

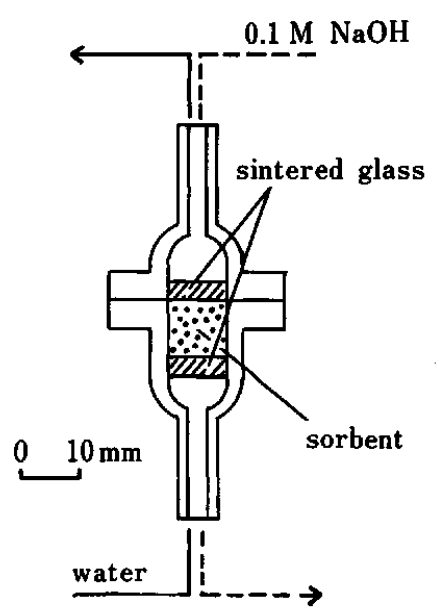

Fig. 1 Concentration column. 
$0.1 \mathrm{ml}$ of $1 \mathrm{M}$ sodium hydroxide is added to redissolve humic acid, and the solutions in both tubes are combined, neutralized with $1 \mathrm{M}$ hydrochloric acid and diluted to $10 \mathrm{ml}$, and the absorbance $(B)$ of the solution is measured at $\mathbf{p H ~ 7 . ~ T h e ~ a b s o r p t i o n ~ c o e f f i c i e n t s ~ d u e ~}$ to fulvic and humic acids in the original river water are obtained by $A / 50 l$ and $(B-0.1 A) / 50 l$, respectively, where $l$ is the optical path length of a cell. The concentrations are calculated by reference to the standard solutions described previously.

\section{Results and Discussion}

Concentration of humic substances by sorption

The XAD-7 resin (macroreticular nonionic polymer) was investigated first. ${ }^{8}$ In this case, $500 \mathrm{ml}$ of water samples have to be acidified to $\mathrm{pH} 2$ and passed through a column longer than $10 \mathrm{~cm}$ at a flow rate of $2 \mathrm{ml} \mathrm{min}^{-1}$ for satisfactory sorption of humic substances. Desorption recoveries of humic acid were only $70-80 \%$, though those of fulvic acid were reported to be more than $90 \%{ }^{8}$

Dextran gel and cellulose anion exchangers were investigated next; here humic substances in $500 \mathrm{ml}$ of water were quantitatively sorbed on a $1-\mathrm{cm}$ column at a flow rate of $5 \mathrm{ml} \mathrm{min}^{-1}$ at neutral $\mathrm{pH}$. Their desorption depended on the functional groups and matrix compositions of anion exchangers and on the eluent composition. DEAE-Sephadex A-25 is a weak-base anion exchanger previously used by the present authors for the separation of heavy metals associated with humic substances in fresh waters; 9 it gave a desorption recovery of $c a .100 \%$ for humic substances with $10 \mathrm{ml}$ of $0.1 \mathrm{M}$ sodium hydroxide- $0.5 \mathrm{M}$ sodium iodide. But this eluent was not suitable for the present work, because iodine produced near $\mathrm{pH} 1$ interferes with the spectrophotometric determination of humic substances. Desorption recoveries with $10 \mathrm{ml}$ of $0.1 \mathrm{M}$ and $0.5 \mathrm{M}$ sodium hydroxide were only 13 and $21 \%$ for humic acid, respectively. DEAE-cellulose, a weak-base anion exchanger recommended by Miles et al. ${ }^{10}$, was finally selected, because desorption recoveries of humic and fulvic acids sorbed on the column were 91 and $95 \%$, respectively, with $10 \mathrm{ml}$ of $0.1 \mathrm{M}$ sodium hydroxide.
Backward-flow elution improved the recoveries of humic substances.

Iron in the sample, which interferes with the spectrophotometric determination of humic substances ${ }^{7}$, is satisfactorily removed during this step.

\section{Separation of humic and fulvic acids by centrifugation}

Figure 2 shows that humic acid remaining in the supernatant solution $(\mathrm{pH} 1)$ decreases with decreasing sedimentation coefficient, which is $\ln \left(x_{2} / x_{1}\right) / \omega^{2} t$, where $x_{1}$ and $x_{2}$ are the initial and final distances of the particle from the axis of rotation, $\omega$ is angular rotation velocity, and $t$ is the centrifugation time. Humic acid was quantitatively separated by centrifugation at 14000 $\mathrm{min}^{-1}$ for $72 \mathrm{~min}$, while fulvic acid remained in the solution. Better results may be obtained by centrifugation at $50000 \mathrm{~min}^{-1}$, but an ultracentrifuge has to be used.

\section{Application to river water}

The proposed method was applied to the determination of humic substances in river water, with the results shown in Table 1. The blank value through the whole procedure was negligible. Fulvic acid is predominant in this river water. The analytical results for humic acid

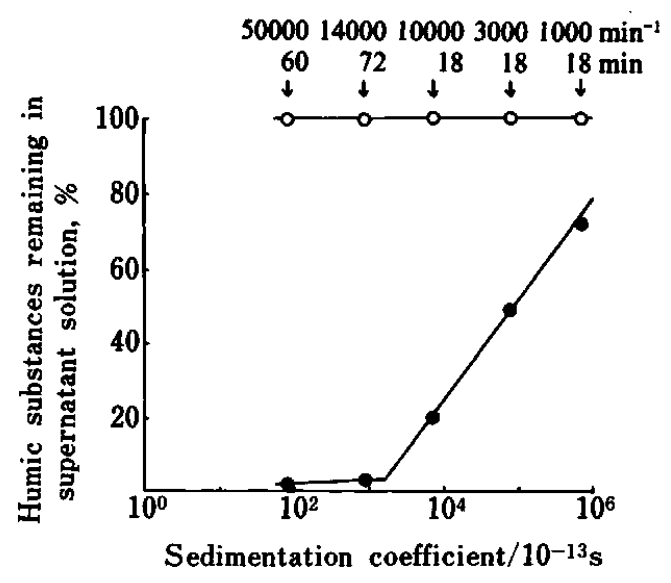

Fig. 2 Sedimentation of humic and fulvic acids at $\mathrm{pH} 1$ by centrifugation: (O) humic acid, $5 \mu \mathrm{g} \mathrm{ml}^{-1} ;(O)$ fulvic acid, $100 \mu \mathrm{g} \mathrm{ml}^{-1}$.

Table 1 Separation and determination of humic and fulvic acids in river water (Shōnai River, Nagoya)

\begin{tabular}{ccc}
\hline Technique used & $\begin{array}{c}\text { Absorpton coefficient of river } \\
\text { water } / 10^{-4} \mathrm{~cm}^{-1}\end{array}$ & $\begin{array}{c}\text { Concentration in river water/ } \\
\mu \mathrm{g} \mathrm{m} \mathbf{l}^{-1}\end{array}$ \\
\hline Anion exchange and centrifugation & 39 & 2.3 \\
Fulvic acid & 38 & 2.2 \\
Humic acid & 5.1 & 0.027 \\
& 6.5 & 0.034 \\
Coprecipitation and flotation & & 0.037 \\
Humic acid & 7.1 & 0.045 \\
\hline
\end{tabular}


obtained by the proposed method are in fairly good agreement with those obtained by coprecipitation with hydrated iron(III) oxide followed by flotation, considering that there are differences in separation mechanism between the two.

\section{References}

1. T. M. Florence and G. E. Batley, CRC Crit. Rev. Anal. Chem., 9, 219 (1980).

2. K. Urano, H. Wada and T. Takemasa, Water Res., 17, 1797 (1983)

3. M. Hiraide, F. Ren, R. Tamura and A. Mizuike, Mikrochim. Acta [Wien], 1987 II, 137 (1988).

4. S. Boggs, Jr., D. G. Livermore and M. G. Seitz, Rev.
Macromol. Chem. Phys., C25, 599 (1985).

5. E. M. Thurman and R. L. Malcolm, Environ. Sci. Technol., 15, 463 (1981).

6. S. Arai and K. Kumada, Soil Sci. Plant Nutr., 29, 543 (1983).

7. T. Nomizu, M. Sanji and A. Mizuike, Anal. Chim. Acta, 211, 293 (1988).

8. G. R. Aiken, E. M. Thurman, R. L. Malcolm and H. F. Walton, Anal. Chem., 51, 1799 (1979).

9. M. Hiraide, S. P. Tillekeratne, K. Otsuka and A. Mizuike, Anal. Chim. Acta, 172, 215 (1985).

10. C. J. Miles, J. R. Tuschall, Jr., and P. L. Brezonik, Anal. Chem., 55, 410 (1983).

(Received December 28, 1988)

(Accepted April 1, 1989) 